\title{
IDEAS OF SYMMETRY AND HARMONY IN THE NATURAL SCIENCE WORK OF ABU ALI IBN SINA
}

\author{
Bekpulatov Ulugbek Rakhmatulla ugli \\ Doctor of philosophy (PhD), Navoi State Pedagogical Institute. Uzbekistan
}

Article DOI: https://doi.org/10.36713/epra5423

\begin{abstract}
In the article, analyzing the role of the ideas of symmetry and harmony, we will see that these ideas were the methodological regulatory basis for the promotion of natural science creativity of Ibn Sina. The thinker paid special attention to the principles of symmetry as perfection, harmony, conservation, rhythm, and measure for achieving benefit and allowed to explore many traditional problems of the philosophical, natural, and medical Sciences from new positions, in the light of new conceptual approaches different from Greek, ancient science.
\end{abstract}

KEYWORDS: quantities, qualities, symmetry, harmony, matter, inertia, conservation, order, chaos, beauty, rhythm, conservation.

\section{INTRODUCTION}

In modern conditions of globalization, moral war and struggle for human consciousness, it is natural that adding to our national thinking the works of our ancestors and their unique ideas is a worthy shield against any social problems. From this point of view, we should be proud to say that the exemplary life and work of our great thinkers and thinkers, our outstanding scientific and creative discoveries have charmed the world community in the past and today, - said the President of Uzbekistan Sh.M. Mirziyoyev [1].

Central Asia played a significant role in connecting the two great civilizations - Western and Eastern, being a kind of guide for both sides. During the early middle ages (VII - XI centuries), the leading role in the development of science was played by thinkers of Uzbekistan, which is located in the center of Central Asia. The specifics of the revival of spirituality and the introduction of Uzbekistan to regional civilizational processes is that our country is located on the territories of the States of ancient Turan, Maverunnahr, and Turkestan. For this reason, the territory now called Uzbekistan is considered one of the cradles of civilization and science not only in the East, but also in the whole world, and this is recognized by the whole world. Indeed, the roots of science and philosophy in our country, which created such a great work as "Avesta" three thousand years ago, there is no doubt that it is as ancient as the philosophy of China or Greece, Egypt and India. Not without reason, such recognitions as "the age of Avicenna", "the age of Khorezm", "the age of Beruni", "the age of Ferghani" appeared in the history of science, and among the peoples of the East such expressions as "Samarkand - perfection on earth", "Bukhara - the power of Islam". Khorezm Academy of Mamun, Samarkand Academy of Ulugbek, at one time was not only the Academy of exact Sciences, but also the Academy of philosophy... In this sense, there is every reason to say that our national philosophy and science are as ancient as our history, as deep as our spirituality [2;161$165]$.

In the synthesis of scientific, philosophical and cultural trends of the East and West during the middle ages, Central Asia was initially the Keeper of ancient traditions, then scientists in the centers of education and science assimilated and processed the ancient heritage, promoting further and more accurate representation of the world.

In Eastern medieval geometry, and astronomy, in arithmetic, and the science of music, and finally in medicine, the doctrine of symmetry and harmony allowed us to explore many of the traditional problems of these Sciences from new positions, in the light of new conceptual approaches that differ from Greek and ancient science. And 


\title{
EPRA International Journal of Research and Development (IJRD)
}

\author{
Volume: 5 | Issue: 10 | October 2020
}

- Peer Reviewed Journal

caused the science of this era to receive achievements of lasting world significance. The idea of harmony as having a universal character is Central to the aesthetics of the Muslim middle ages $[3 ; 41]$. It is associated not only with the structure of the Universe, but also with specific Sciences. In the art of architects, perfection (harmony, symmetry) was achieved by means of geometric ornaments, in harmony the most important elements of human life, the harmony of the plant world is revealed, etc. [4; 7].

The greatest influence on the formation of philosophical, natural - scientific creativity of Abu Ali Ibn Sina (Avicenna) was exerted by the works of al-Farabi, whom he called his second teacher after Aristotle.

The main philosophical work of Ibn Sina was the encyclopedic work "The book of healing", consisting of four sections: logic, physics, mathematical Sciences (geometry, arithmetic, music, astronomy) and metaphysics. The book of knowledge (Danish-nameh), written in Farsi, echoes this work. Ibn Sina considered physics an essential part of his philosophical system. Logic is an extension of physics and is considered a method of cognition. The next element is metaphysics, which studies being.

We will give the place of the idea of symmetry and harmony in the scientific work of Abu Ali Ibn Sina and consider how important they are today.

\section{DISCUSSION}

Ibn Sina's scientific views $(980$ - 1037) were formed in Bukhara, the capital of the Samanid state, when this city was one of the largest cities in the "Muslim East". Bukhara at that time (X century) was important not only as a center of handicraft, trade, administrative and political life of Transoxiana, but also as a scientific and cultural center of the entire "Muslim East". The scientist managed to learn the essence of Aristotle's "Metaphysics" through the works of Farabi. According to Ibn Sina himself, he read Aristotle's Metaphysics forty times, knew the text of the book by heart, but could not understand the essence of Aristotle's ideas, and this was only possible with the help of Abu Nasr Farabi's commentary on Aristotle's Metaphysics [5; 16].

Symmetry is a fundamental property of nature, the idea of which has been formed for tens, hundreds, thousands of generations. In ancient times, the word "symmetry" was used in the sense of "harmony", "beauty". Indeed, translated from Greek, this word means "proportionality, proportionality, sameness in the arrangement of parts.

For Abu Ali Ibn Sina, the principle of perfection is very important. Perfection is achieved through harmony, where preservation is important: "Perfection consists in the fact that everything necessary for its preservation exists to the extent that it is worthy of its essence" $[6 ; 123]$. Conservation is "not only necessary" to achieve perfection (harmony), but also (serves for ... good). Thus, for Ibn Sina, the principle of symmetry serves to achieve benefits.

Ibn Sina States that nature is harmonious in itself compared to man. He gives an anthropological interpretation of harmony, seeks to find its principles in the structure of the human body and in the spiritual appearance of man. He did not seek to establish a connection between the state of the sky, the properties of the soul, and musical intervals, as the Pythagoreans did. He criticized the Pythagoreans for not "distinguishing one science from another" in their teaching $[6 ; 126]$

For Ibn Sina, symmetry is directly related to form, but form cannot exist without matter. Objecting to Aristotle's preference for form, he wrote: "Each form, being the sole cause of the existence of matter, if it disappeared, would lead to the fact that matter would not exist. Nor can it be that forms would not be real, and would not participate in bringing matter into the state of reality, otherwise matter could exist without form" [7; 5-9] concluding that "corporeal form does not exist without matter", he rejected Plato's idealistic position on things as disembodied concepts as "useless". Recognizing that numbers actually exist in things, he rejected the mysticism of the Pythagoreans' numbers.

Ibn Sina argued that in accordance with the "true philosophy" (i.e., the advanced view of his time), a plane that again exists in the form of a body located in matter [8; 75]. This rejected all mystical revelations based on the magic of numbers and affirmed the role and significance of methods of applied mathematics.

Beauty is inextricably linked to symmetry. It expresses the highest expediency of the world structure, confirms the universality of mathematical laws that work equally effectively in crystals and living organisms, in works of art and in scientific discoveries.

In aesthetics, the concept of symmetry is traditionally associated with harmony, beauty, and order. For this reason, the problem of beauty is Ibn Sina's main aesthetic category. It includes types of manifestation of such categories as "harmony", "perfection", "rhythm", "measure". The problem of beauty in music in Ibn Sina is consonant with the ideas of al-Farabi, set out in the "Great book of music" and other treatises. The harmony of the whole musical work is understood by Ibn Sina in connection with its artistic and aesthetic value. "Sound can be pleasant or unpleasant for the soul in other ways: either from the point of view of the mood it creates, or from the point of view of the composition. The pleasure or disgust caused by both is peculiar to the differing power of the animal soul, but not to the sense of hearing as such" $[5 ; 23]$.

Music in Ibn Sina is the same object of love, since it was considered a perfect and beautiful phenomenon with qualities (harmony and proportionality), and he attributed it to the category of beautiful images in General. "Both the mind and the animal soul... always love what is harmonious, harmonious, and proportionate, such as harmonious sounds" $[9 ; 58]$. Harmony in music, as a certain abstract category, including a number of specific manifestations at various levels of a musical work, which were dictated by the aesthetic needs of musical practice. In no case should it be identified only with the ratio of two tones - the interval. Perhaps the interval is the initial level of harmony of a piece of music. Not every combination of two tones in height can be considered harmonious, but only what gives a person pleasure. At the same time, the harmony and proportionality of the two tones is adequately 


\title{
EPRA International Journal of Research and Development (IJRD)
}

\author{
Volume: 5 | Issue: 10 | October 2020
}

- Peer Reviewed Journal

conveyed by the musical term "consonance" (in Ibn Sina Ittifak).

Time is the main element in the formation of musical reality, the basis of musical timing is rhythm, and rhythm is the basis of any of the temporal events. They can be found in the case of identifying specific factors that do not lie on the surface of asserting the relationship of music and temporal processes based on their inherent temporality, but are hidden in the ontological essence of musical laws that reflect any development processes. The musical rhythm, the sense of tact, gave rise to the human pulse of blood. "As the art of music, writes Ibn Sina, is accomplished by combining sounds in a certain ratio of sharpness and severity, and by the circle of rhythm, the size of the time intervals separating the strokes on the strings, so is the quality of the pulse beats. The ratio of the rapidity and frequency of their tempo is a rhythmic ratio, and the ratio of their quality in strength and weakness and in magnitude is a combination ratio. Just as the tempo, rhythm, and dignity of sounds are consonants, and there are dissonants, so the irregularities of the pulse are ordered, and there are disordered" [5; 17]. It can be logically assumed that time, which is related to the rate of rhythmized division, is subjective for each becoming system, which suggests a broken symmetry between time flows. And, for this reason, Ibn Sina also speaks about the presence of biological rhythms in the body, tissues, organs, that they are closely related to the rhythm of the environment, to learn to read the interaction of these rhythms through the pulse, to feel a single pattern in them, a certain music, which can be safely attributed to the highest achievements of medical thought.

And this is Biophysics, which is widely studied in modern therapy: sinus arrhythmia of the heart, for example, Ibn Sina distinguishing 48 types of pulse by ten parameters.

Ibn Sina's Statement of the problem of the transition from rectilinear to curved motion within the framework of the natural scientific achievements of his time is admirable. Later, this idea will be developed by Galileo, Descartes, and Newton. And Galileo 600 years after Ibn Sina formulated the law of unity of rectilinear and curvilinear motion as two forms of the same mechanical motion.

Scientists of the world are still thinking about this problematic movement. According to the law of uniform rectilinear motion, an spike grows, a spaceship, a bullet, a bird flies, blood flows in the veins, oil flows in the pipes, crystals and children grow, poems are arranged in musical harmonic compositions [10;222-223]. Ibn Sina to say "if in the nature of rectilinear motion there is an admixture of the opposite in its nature, then the motion becomes less rectilinear", that is, This turbulent motion gradually rounds off - the number one problem in modern physics. This movement is due to the chaotic displacement, decay, death and birth, of countless vortices - large and small, not amenable to any mathematical certainty.

Without mastering the laws of this movement, we will not be able to understand the flow of water in the ocean, winds in the atmosphere, helium and hydrogen in the bowels of the sun, the flow of oil in powerful continental pipelines, calculate how the Earth's climate will change, radioactive radiation will spread, wind will RUB against seas and continents, and heat and moisture will be transferred from the Earth's surface to the atmosphere.

These movements were always considered completely disordered. However, they are also described by some very universal laws and are subject to strictly justified distributions. Knowing some initial characteristics of a statistical ensemble, you can make some predictions about the expected movement and calculate certain parameters of it. What if we don't know how a single particle of the ensemble moves, its movement, as a rule, doesn't interest us. Although something can be said about its movement in advance, for example, that between collisions with other particles it will move in a straight line and will not leave the specified volume, etc. Such a chaotic motion as turbulence also obeys certain laws, i.e. the Navier-Stokes equations, and turbulent flows arise from laminar flows when the Reynolds number increases, i.e. dynamically.

The discovery of Ibn Sina is also his teaching about "impulse", "aspirations", "violent movement", i.e. the preservation of the movement of the moving body. "How", thought the philosophers, "does the violent movement of the body continue after it has been detached from the source of motion?" Aristotle believed that the force of the hand that threw up, say, an Apple, is transmitted to the air, and the air pushes the Apple, and therefore it moves. 900 years after Aristotle, the Alexandrian scientist John Philoponus said: the environment does not help, but rather hinders movement! It is not the environment that makes the movement, but the driving force. Further development of the theory of the driving force was carried out by Ibn Sina, introducing the concept of "ASPIRATION" (IMPULSE). It supports the driving force until it completely disappears, until that instantaneous state of rest, instantaneous stop, after which the violent movement ends. Through the Western Arab scholars Ibn Badj, al-Bitruji is Ibn Sina's teaching of ASPIRATION (IMPULSE) came in the THIRTEENTH century to the University of Paris, where albert the Great directly refers to Avicenna in the presentation of this question. Finally, it was strictly formalized by J. Brudan[10;225].

Ibn Sina's discovery was also His justification of INERTIA as a principle of motion. This idea was introduced into the law only 600 years later by Galileo. Studying the phenomena of inertia, physicists came to the conclusion that each physical body has the property of changing its speed in a certain way under the influence of this influence, which is expressed by a certain physical quantity called an inert mass. Careful research has shown that the inert and gravitational masses are numerically equal to each other and are, as it were, two manifestations of the same property of bodies. Ibn Sina says that life is an eternal circular movement, the only eternal movement on earth that is driven by the enmity of two opposites: change (asymmetry) and conservation (symmetry). Change is life. Saving is death. When a person dies, they will dissolve into the earth, which returns to the eternal preservation of matter, the eternal presence of material particles, of which 


\section{EPRA International Journal of Research and Development (IJRD) \\ Volume: 5 | Issue: 10 | October 2020 \\ - Peer Reviewed Journal}

you were composed in nature. And life is a change in a new connection, a new body that has just been formed, and its development. Nothing in the world is destroyed. Even the universe itself is preserved. Giordano Bruno, Denis Diderot, and the 17th-century French mathematician and philosopher P. Gassendi also said this when developing this idea.

\section{CONCLUSION}

In any science, Ibn Sina mastered not only all the achievements of his predecessors, but also made a significant contribution to their development, enriched them with personal observations and reflections; systematized them, corrected errors, eliminated gaps and ambiguities, excluded all unreliable, reduced and publicly stated.

Until the XVIII century the main universities in France, Italy, England, Germany and other countries more than 600 years studying Ibn Sina's "Book of healing", consisting of 22 volumes, "the knowledge Book", "Book of salvation", the "Canon of medical science", as the first translation from Arabic into Latin made by Gerard of Cremona in the XII century by order of Frederick Barbaros.

His greatness as one of the scholarsencyclopedists of the middle ages, is reflected in the immeasurable legacy, his contribution to the development of many Sciences, not only the era, but many millennia ahead.

\section{REFERENCES}

1. Sh. Mirziyoev (2017) Vistupleniye Prezidenta Respubliki Uzbekistan Sh. Mirziyoyeva na Generalnoy Assambleye 72 oy sessiy Generalnoy Assambley OON. 19 sentyabrya 2017 goda. SSHA. Nyu-York

2. Karimov, N., \& Karimova, Z. (2019). Uzbek philosophy: past and present. ISJ Theoretical \& Applied Science. 11 (79), - p.161-165.

3. Sagadeyev A.(1988) Garmonichnbly chelovek. - M., -141 p.

4. Abdullayeva M.N. (2016). Simmetriya v prirode. Sbornik state Respublikanskogo nauchno-teoriticheskogo konferensii. Mesto nauchnble naslediye sentralnble Azii v chelovecheskom sivilizatsii. Tashkent, -195 p.

5. Bekpulatov U.R. (2017). Simmetriya $v$ proshloy $i$ sovremmenoy nauke. (monografiya). Saarbrücken, Deutschland/Germaniya. LAP LAMBERT Academic Publishing. p.108.

6. Ibn Sina. (1980). Danish-Nama, Kniga znaniya. Izboan. Proizv. T.!. Dushanbe: Irfon.-420 p.

7. Bulatov M.S. (1978) Geometricheskaya garmoni- zatsiya v arxitekture Sredney Azii 9-15 vv. M.; "Nauka".

8. Shirinova N. Dj., Xaydarov I.M. (2012). Sinkretnost $i$ diffuziya predmetnosti $i$ kachestvennosti $v$ ob'ektivnoy deystvitelnosti. Nauchniy Vestnik Buxarskogo Gos. Universiteta. 4(48). -151 p.

9. Serebryakov B.S. (1976) Traktat Ibn Sinbl (Avitsenni) o lyubvi.-Tbilisi: Metsniyereba, -203 p.

10. Saldadze L. (1983) Ibn Sina Avitsena. -Tashkent. Izdatelstva Literaturi i iskusstva im. G. Gulyama. -464 p.
The first printed edition of Ibn Sina's books in 1473 - 1479 in Padua, in 1482 and 1500 - in Venice, in 1543 - in Rome in the Medici printing house, in Arabic, and in 1593 - in French. in the XV century, Kiev, Novgorod, and Moscow got acquainted with the "Ovsinev wisdom". Many of the information in this book is still used by doctors today.

Assessing Ibn Sina's contribution to the development of world science and culture, Giordano Bruno put Him on a par with the great philosopher of ancient Greece Aristotle and the healer Galen. The famous Dante in his "divine Comedy" equated Ibn Sina with Ptolemy, Euclid and Hippocrates. The German philosopher L. Feuerbach called him "A famous doctor and philosopher", and the outstanding statesman of India, J. Nehru in his book "the discovery of India", mentioning the scientists of Central Asia, separately focusing on the personality of Ibn Sina, said: "The most famous among them, who received the title of king of physicians, is Bukharian Ibn Sina (Avicenna)." Contemporaries called Ibn Sina as "Sigur-Rais" ("Commander of the sages, the chief of the scholars"), "Sharaf al-Mulk" ("Credibility, pride of the country") .... 